\title{
Community-based tourism: concepts, opportunities and challenges
}

Aditha Agung Prakoso ${ }^{1 *}$, Eugenius Pradipto², Muhammad Sani Roychansyah ${ }^{3}$, Bima Setya Nugraha $^{4}$

Department of Architecture and Planning, Gadjah Mada University, Yogyakarta, Indonesia ${ }^{1,2,3}$

Faculty of Law, Gadjah Mada University, Yogyakarta, Indonesia ${ }^{4}$

aditha.agung.p@mail.ugm.ac.id ${ }^{1 *}$, e.pradipto@ugm.ac.id ${ }^{2}$, saniroy@ugm.ac.id ${ }^{3}$,

bima.setya.nugraha@mail.ugm.ac.id ${ }^{4}$

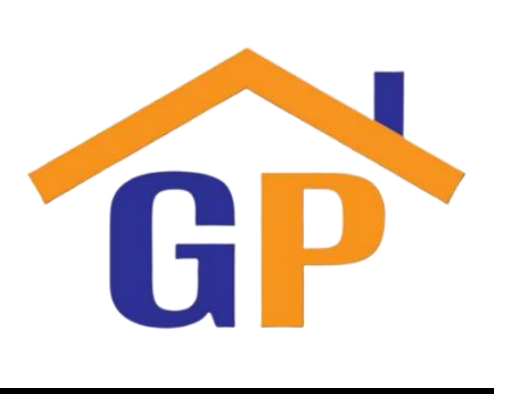

Article History

Received on 6 May 2021

Revised on 4 June 2021

Accepted on 6 June 2021

\begin{abstract}
Purpose: The community-based tourism concept needs to be understood deeply. We need to know and predict the opportunities and challenges that exist and will occur in the future in developing the community and tourism as a mutualism. This research analyzed the theories to describe it and derive conclusions for the basic concepts of community-based tourism as well as further explore the cases of applying these concepts to gain opportunities and challenges from community-based tourism
\end{abstract}

Research methodology: This study is a conceptual article using the literature review method

Results: This study elaborates the concepts, opportunities and challenges of the community-based tourism paradigm.

Limitations: This study is a secondary data-based analysis (literature review) on the concept of community-based tourism in the social and cultural context of the community, as well as the opportunities and challenges of its application to tourism development

Contribution: This study provides an in-depth and comprehensive view of community-based tourism to assist in exploring approaches and theories in community-based tourism research and planning and policymaking in the tourism sector, especially in the local community aspect.

Keywords: Tourism, Community, Community-based tourism, Concepts, Challenges

How to cite: Prakoso, A. A., Pradipto, E., Roychansyah, M. S., \& Nugraha, B. S. (2020). Community-based tourism: concepts, opportunities and challenges. Journal of Sustainable Tourism and Entrepreneurship, 2(2), 95-107.

\section{Introduction}

Tourism has always been seen as a sector capable of improving people's welfare, opening up vast employment opportunities, and supporting people's economic income. However, experts argue that this sector does not always have a positive impact on people's lives. Deller (2010) argues that tourism is often identified with poverty because jobs in the tourism sector lead to low-income jobs and do not guarantee the community's welfare to get a higher income. One form of tourism activity that is directly related to the community is community-based tourism. Initially, community-based tourism was present as an alternative form of tourism to overcome the mass/conventional tourism phenomenon. Community-based tourism should be managed and owned by the community, where the community gets direct benefits from these tourism activities. However, along with community-based tourism development, experts try to give their opinion about the other side of community-based tourism. For example, Blackstock (2005) states that community-based tourism is "naive and unrealistic"; besides, it is only a slogan. Although community-based tourism's basic concept is community empowerment, 
community-based tourism is only used as a tool to maintain economic stability and legitimize tourism activities as a local "interest". Many other studies on community-based tourism that explain communitybased tourism are only limited to explaining concepts or simply discussing problems that are often found in their application. However, it needs to be explained in detail so that it can be understood and implemented. So the purpose of this article is to try to describe a good and clear understanding of community and tourism, the concept of community-based tourism, and the opportunities and challenges that exist and will occur in the future.

\section{Literature review and hypothesis development}

Community-based tourism has become the theme of many works of researchers. In this section, researchers try to explore the writings on community-based tourism to be able to find the emerging research gaps so that this research can fill the research gaps. Johnson (2010), in his paper, explains the potential for realizing community-based tourism through social economy-based enterprises (social economy enterprises) by providing examples of various forms of business so that community-based tourism is used as a tool to achieve a goal that has economic benefits. Carr et al. (2016) explore the original culture and cultural heritage of a community, which can be a community-based tourism resource. This is considered very strategic because, in addition to having economic benefits, tourism can also be a tool to preserve native culture by elevating it as a tourist attraction, so that the role of community involvement is essential, not only as workers but also as tourism planners and managers (Nechifor, 2014). Besides, Campbell and Vainio-Mattila (2003) raised that community-based tourism development provides alternative opportunities for tourism activities that have conservation value and community participation. Dimitrovski et al. (2012), looking at how the development of communitybased tourism in Gruza Village, found that tourism is an essential tool in increasing income and preserving local cultural identity. However, limited resources, human resources, and local capital in the village are still obstacles to being a good host. In line with these studies, Liu (2010) also stated that the development of rural areas in Taiwan could be carried out through tourism activities, so that rural areas will be visited by tourists and can help the goals of successful rural economic development. These studies clearly show that community-based tourism has good opportunities for preserving culture and increasing local income.

The development of community-based tourism does not always have a positive impact on local communities. On the other hand, community-based tourism is considered a concept or theory and can even be seen as something naive and unreal (Blackstock, 2005; Ghaderi and Henderson, 2012). Also, $\underline{X i}$ et al. (2015) explained that tourism development in rural areas poses a risk of natural damage and land diversion. This is like what happened in Gougezhuang Village, Yesanpo, China, where forest land was converted into tourism accommodation land, residential land was converted into tourism accommodation and entertainment land, and other land transformed into tourism shopping and catering land. Salazar (2012) explains the shortcomings of community-based tourism, especially regarding the limited quality of human resources in receiving guests, including cleanliness, accommodation that does not have good standards, and guiding tourists. Mtapuri and Giampiccoli (2016) added the importance of the role of local resources as the spearhead of community-based tourism development, so it needs assistance from third parties. However, this assistance also has problems when the dependence of local communities on the facilitator arises.

Some of the studies described above place community-based tourism as the main theme, focusing on discussing the positive and negative impacts that arise in the application of community-based tourism. However, the discussion of this concept is still not comprehensive, so this paper elaborates Communitybased Tourism: Concepts, Opportunities, and Challenges; it explains coherently what the concept of community-based tourism looks like, as well as the opportunities and challenges that will arise when developing this concept in tourism activities. 


\section{Research methodology}

This article is of the type of conceptual articles using the literature review method. The literature review method is a critical review of the theory, findings, and other research materials obtained from reference materials to serve as a basis for developing a clear frame of mind from the formulation of the problem, in this case explaining the concepts, definitions, principles, and terminology of community-based tourism. Literature reviews contain reviews, summaries, and writers' thoughts on several literature sources (books, articles, and information from websites) on the topics discussed.

Several steps were taken in the literature review method in this article, including:

i. Formulating problems and topics, in this case, community-based tourism

ii. Determining the literature that is relevant to the concept of community-based tourism as well as opportunities and challenges in implementing community-based tourism

iii. Evaluating data from the literature that has been selected and sorting out data sources that have a contribution and are under the needs of the discussion topic (concepts, opportunities, and challenges)

iv. Analyzing and interpreting the data according to the topic to find concepts, opportunities, and challenges in the implementation of community-based tourism.

v. Concluding the perspective on community-based tourism, especially regarding concepts, opportunities, and challenges.

\section{Results and discussions}

\subsection{Community and tourism}

Tolkach and King (2015) explain that community refers to a geographical location that is autonomous and has common interests and needs as well as a sense of shared identity. Koentjaraningrat (2015) argues that community is a unity of human life that occupies a real area and interacts according to a system of customs bound by a sense of shared identity. This is also explained by Koentjaraningrat (2015), who explains that communities have a bond of location (locality) and a sense of community identity (community sentiment). This definition of a community is reinforced by the fact that the community is a group of people who are interrelated by the ties of the same location and interests (Siwi, 2012). Siwi (2012) emphasizes the concept of community through a community of interest, high interaction between people (an attachment community), and have everyday needs.

According to Crow and Allen (1994), a community can be divided into two components:

i. Based on similarities in location and geography

ii. Based on similar interests (religion, occupation, ethnicity, race, and even hobbies)

As a community, there needs to be an understanding of the sustainability of the values of a community itself, so there needs to be an effort to maintain the existence and accommodate the needs and interests of the community itself (Veriasa and Waite, 2017). Kottak (2011) explains Malinowski (1922) view, which uses the term functionalism of needs, that humans have basic needs and naturally develop habits to meet these needs, basic biological needs, including nutrition, reproduction, physical comfort, safety, movement, health, and growth. These habits can be in the form of food preparation and processing, food distribution, regulations, or policies on food production.

Radcliffe-Brown (1952) mentions that there are three adaptation systems of human social life. The first is that social life will adapt to the physical environment, and this is called ecological adaptation. The second is the institutional social adaptation that regulates the institutions that maintain and regulate social life. The last is a cultural adaptation in which there is a social process for individuals to acquire habits and mental characteristics appropriate to social life and participate in them.

According to Veriasa and Waite (2017), two things can be done in this effort: ecological revitalization and service provision by the community; and developing their capacity by building capacity, community organizing, and achieving community interests. This is often referred to as community development. 
There are basic values of community development, including the following (Veriasa and Waite, 2017):

1. Participation: in this context, participation is not only participating but also directly being involved in decision making.

2. Empowerment: power (strength), and utilization are the essence of empowerment, not limited to capacity building and provision of assistance

3. Ownership: community development activities should be able to create awareness of a change of view that community development activities belong to the community itself and for their future so that they are fully responsible for their success.

4. Social capital or Institutional capital: social capital is an accumulation of various types of social, psychological, institutional culture, and intangible assets that influence cooperative behavior. Social capital can only be felt when there have been interactions with other people who are guided by social structures

From these values, tourism can be an appropriate sector to be applied in community development. Tourism is believed to have a good impact in preserving local ecology and culture (Nair and Hamzah, 2015), improving the national economy and local communities (Gezici et al., 2006; Johnson, 2010; Liu, 2010), even alleviating poverty and providing equality or justice (APEC, 2014; Dangi and Jamal, 2016; Deller, 2010; Ghaderi and Henderson, 2012) Tourism is one sector in the development of a region; this sector is very dynamic in capturing various global development trends. Tourism is a dynamic sector and is very responsive to various trends and developments in new life values. Reflecting on global developments and consumption patterns of tourists, especially foreign tourists, today there are many special interest tourists whose orientation is no longer shackled by natural beauty but rather an interaction of both culture and local communities. There has been a significant trend in the last two decades, namely, the special interest tourism market segment has influenced developments that emphasize the role of local communities in tourism activities.

Local communities have a very important role in tourism development. Planning and management by local communities can create sustainability in the tourism industry. Thus, the development of the tourism industry is highly dependent on their involvement, role, and good reception towards tourists (Blackstock, 2005). Ying and Zhou (2007) also explained that the community is a homogeneous environment that is right for tourism development, so it is believed that community and tourism are a good combination in tourism development, especially in tourism based on local values. It is managed directly by the local community and also provides direct benefits to the environment and community.

Community-based tourism is a form of participatory planning in tourism development. As explained by Denman (2001) that in the concept of community-based tourism, local communities have a large role in the sustainability of local tourism, namely as owners and being fully involved in the development and management of local tourism. From the role of the community, it is hoped that it will produce a large impact or benefit and the largest proportion can be absorbed by the community itself. Besides, for tourism development to run and be well managed, the most basic thing to do is how to facilitate the broad involvement of local communities in the development process and maximize the value of social and economic benefits from tourism activities for local communities. Therefore, local people have an equally important position as stakeholders in tourism development, apart from the government and private industry (Sunaryo, 2013; Walkowski et al., 2019).

Nurhidayati and Fandeli (2012) define community-based tourism as tourism that takes into account and places environmental, social, and cultural sustainability, regulated and owned by the community, for the community. Furthermore, Nurhidayati and Fandeli (2012), trying to see community-based tourism not from an economic perspective first but from a perspective of community and environmental capacity building, while the economic aspect becomes an 'induced impact' from social, cultural, and environmental aspects, so it is hoped that community development in tourism will be sustainable. A community in the perspective of tourism is explained by Dangi and Jamal (2016) as groups who live in an area and interact with tourists in a travel experience. This community plays a role as the main actor or backbone in implementing tourism (Adimihardja, 1999; Hasanah, 2017; Yotsumoto et al., 2016). Thus, tourism emerges and is managed directly by the community. 
In practice, community-based tourism is developed on a small scale and is managed directly by the community in partnership with other parties (Mtapuri and Giampiccoli, 2016; Nair and Hamzah, 2015), which is called social capital. In addition, it includes cultural capital that is applied by being owned (Goodwin and Santili, 2009; Hadiwijoyo, 2012) and utilizing local resources (Mualisin, 2007; Murphy, 1988; Yotsumoto et al., 2016), especially those based on local cultural traditions and community life.

\subsection{Community-based tourism: social and cultural capital}

\subsubsection{Social capital in community-based tourism}

There are important values that need to be built; these values are participation, empowerment, ownership, and social (institutional) capital (Veriasa and Waite, 2017). These three values can also be used in community development in tourism, especially community-based tourism. Veriasa and Waite (2017) maintain that community development actors should be clear about what kind of participation should occur when mobilising communities in community development activities. Tolkach and King (2015) explain that there is extensive debate about the benefits of participation in tourism development. It is debatable whether there is a genuine understanding of tourism among communities, the exercise of power between stakeholders, and the capacity to achieve community development goals. Furthermore, Veriasa and Waite (2017) emphasized that participation is not the same as participation (involvement). Participation includes the power to make decisions.

Community-based tourism is understood as tourism that is managed and controlled by the community (Mtapuri and Giampiccoli, 2016). Besides, it aims to involve local people in planning, implementation, development, management, and decision-making to create a more sustainable tourism industry that is meaningful to alleviate poverty and provide alternative sources of income and equitably benefit the community (Blackstock, 2005; Dangi and Jamal, 2016; Johnson, 2010; Salazar, 2012). However, the community's existence is seen as an object to be involved in tourism activities but emphasizes their participation. Community-based tourism can be regarded as a community development tool to strengthen the ability of rural communities to manage tourism resources and also involve local community participation (Nair and Hamzah, 2015). It is emphasized that community-based tourism refers to engaging community participation in tourism and aims to gain benefits for the community in developing the world by allowing tourists to visit communities and learn about local culture and environment (Dangi and Jamal, 2016). Community-based tourism is stated as a symbolic relationship where tourists are not given centralized priority but become part of the system (Salazar, 2012). Community-based tourism is also seen as a way in which the private or government sector can meet with communities in the tourism development process. This involves residents and communities not only as "the core of the tourism product" (Johnson, 2010) but as active participants in the development process. In reality, often the community only participates in implementing agendas that have been determined by outsiders (Dolezal, 2011) and decision making usually comes from tourism actors such as government and private investors (Dolezal, 2011). The local community should have an equally important position as a stakeholder in tourism development, apart from the government and private industry (Sunaryo, 2013).

The values of empowerment in community-based tourism also have essential values. Widayanti (2012) defines empowerment as a tool to help individuals, groups, and communities so that they can manage the environment and achieve their goals so that they can work and help themselves and others to maximize their quality of life. Dangi and Jamal (2016) hold that local empowerment and participation in community-based tourism is seen as essential, and the key principle of community-based tourism is a development that utilizes community potential and resources managed by the community, community-based and run by the community (Dangi and Jamal, 2016) and directing the community to gain pro-active control in tourism development, strengthening the ability of local communities to solve any problems without depending on outside parties (Johnson, 2010).

Another important value of community-based tourism is "ownership". However, many issues have developed regarding community-based tourism, particularly regarding ownership and management. As stated by Mtapuri and Giampiccoli (2016), there are issues regarding ownership and management that 
are still debated and ambiguous whether the community manages or owns a business in it, or if it is just about job creation and community participation in decision making. Community-based tourism is usually understood as managed and owned by the community, for the community (Dangi and Jamal, 2016). The idea of "ownership" and participants as "owners" of the process has started to emerge. Campbell and Vainio-Mattila (2003) are of the view that "Ownership" refers to the relationship between stakeholders in development. This ownership has a very high value if the following are met:

i. Providing substantial benefits that impact the concept, design, implementation, operation, and maintenance of the development.

ii. Implementing agencies that influence and represent the interests of citizens.

iii. There is transparent accountability between stakeholders

Community development also considers the importance of social (institutional) capital. According to Veriasa and Waite (2017), in reconstructing social capital, a cooperative, responsible, and active community that is involved, both men and women should be managed and mobilized for mutual aid, self-help, solving problems, social integration, and or social action. Community integration should be promoted in two sets of relationships: "social relations" between the various groups within the community and "structural relations" between institutions involved in community development. Structurally, social capital is an intangible and objective concept that focuses on the community's organisational structure (Musavengane, 2015). The opinion by Inskeep (1991), which states that residents must be directly involved in the planning, development, management, and decision-making processes in community-based tourism, means that in the local community, a forum is needed to accommodate tourism activities, such as organizations or institutions. The opinion supports this by Johnson (2010), who argues that the solution to socio-economic problems in community-based tourism is the development of community organizations as a communication media. The organization in question is a non-profit organization consisting of community stakeholders, citizens, and business owners. This tourism organization can later become a local liaison to provincial, national and international partners. It is clear that this social (institutional) capital is essential in community-based tourism; the institution or organization in question can be a Tourism Awareness Group (Pokdarwis) which functions to mobilize tourism activities in a community.

\subsubsection{Cultural capital in community based tourism}

Cultural capital in community-based tourism is a tourist attraction that results from the existing culture in the area. As stated by Dolezal (2011), culture has a very important role in the role of local communities as hosts to maintain the traditional way of life of society and their culture becomes an attraction for tourists. Thus culture becomes a community asset that is used as a tourist product to create assumptions about cultural authenticity; therefore, tourists must stay close to local communities. According to Koentjaraningrat (2015), the notion of culture is the whole system of ideas, actions, and human work in people's lives that belong to humans by learning. Ahimsa-Putra (2013) interprets culture as a symbol that humans get in the community to adapt and maintain their existence. Furthermore, Ahimsa-Putra (2013) identifies four aspects or forms of culture, including the following:

i. Aspects of ideas or knowledge culture/a complex of ideas, values, norms, rules, and so on.

ii. Linguistic aspects

iii. Behavioral or cultural aspects of behavior/a complex of patterned activities and actions from humans in society.

iv. Material physical or cultural aspects/objects made by humans.

Apart from the elements described above, culture also has elements; the ten elements are religion, classification, communication, games, preservation, organization, health, economy, arts, and transportation (Ahimsa-Putra, 2013). These cultural elements can become an attraction for cultural tourism or cultural capital for the concept of community-based tourism (CBT). 
Table 1. Elements of culture as a tourist attraction

\begin{tabular}{|c|c|c|c|c|}
\hline ELEMENTS & IDEAS & LANGUAGE & $\begin{array}{l}\text { CODES OF } \\
\text { CONDUCT }\end{array}$ & $\begin{array}{c}\text { MATERIAL } \\
\text { ASPECT } \\
\end{array}$ \\
\hline 1. Religion & $\begin{array}{l}\text { Beliefs about the } \\
\text { unseen world }\end{array}$ & Religious Terms & $\begin{array}{l}\text { Rituals, } \\
\text { Ceremonies }\end{array}$ & $\begin{array}{l}\text { Worship } \\
\text { equipment, } \\
\text { houses of worship }\end{array}$ \\
\hline 2. Classification & $\begin{array}{l}\text { Arithmetic, } \\
\text { mathematics }\end{array}$ & Calculation term & $\begin{array}{l}\text { Calculation } \\
\text { activities }\end{array}$ & $\begin{array}{l}\text { Abacus, } \\
\text { computer, } \\
\text { calculator }\end{array}$ \\
\hline 3. Communication & $\begin{array}{l}\text { Grammar, } \\
\text { Semantics }\end{array}$ & Vocabulary & Speaking, Talking & $\begin{array}{ll}\text { Telephone, } & \\
\text { television, } & \text { radio, } \\
\text { internet, } & \text { social } \\
\text { media } & \end{array}$ \\
\hline 4. Games & $\begin{array}{l}\text { Game philosophy, } \\
\text { values, rules }\end{array}$ & $\begin{array}{l}\text { The term, game } \\
\text { discourse }\end{array}$ & Sports, games & $\begin{array}{lr}\begin{array}{l}\text { Books, } \\
\text { schools, } \\
\text { museums }\end{array} & \text { clubs, }\end{array}$ \\
\hline 5. Preservation & $\begin{array}{l}\text { Knowledge, values, } \\
\text { norms, rules }\end{array}$ & $\begin{array}{l}\text { The term, the } \\
\text { discourse } \\
\text { preservation }\end{array}$ & $\begin{array}{l}\text { Teaching, } \\
\text { preservation } \\
\text { activities, learning }\end{array}$ & $\begin{array}{l}\text { Village hall, } \\
\text { house, settlement, } \\
\text { library }\end{array}$ \\
\hline 6. Organization & $\begin{array}{lr}\text { Values, } & \text { norms, } \\
\text { rights } & \text { and } \\
\text { obligations } & \\
\end{array}$ & $\begin{array}{l}\text { The term, } \\
\text { organizational } \\
\text { discourse }\end{array}$ & $\begin{array}{l}\text { Kinship, } \\
\text { association }\end{array}$ & $\begin{array}{l}\text { Village hall, } \\
\text { house, settlement }\end{array}$ \\
\hline 7. Health & $\begin{array}{l}\text { Health knowledge, } \\
\text { illness, medicine }\end{array}$ & $\begin{array}{l}\text { The term, health } \\
\text { discourse }\end{array}$ & Medicine, healing & $\begin{array}{l}\text { Medicine, } \\
\text { medical } \\
\text { equipment }\end{array}$ \\
\hline 8. Economy & $\begin{array}{l}\text { Knowledge } \\
\text { flora, fauna, soil, } \\
\text { water }\end{array}$ & $\begin{array}{ll}\text { The } & \text { term, } \\
\text { discourse } & \text { about } \\
\text { beauty } & \end{array}$ & $\begin{array}{l}\text { Dancing, singing, } \\
\text { painting, carving }\end{array}$ & $\begin{array}{l}\text { Hunting } \\
\text { equipment, } \\
\text { farming, raising } \\
\text { livestock }\end{array}$ \\
\hline 9. Expression & $\begin{array}{l}\text { Knowledge about } \\
\text { beauty, good }\end{array}$ & $\begin{array}{ll}\text { The } & \text { term, } \\
\text { discourse } & \text { about } \\
\text { beauty } & \\
\end{array}$ & $\begin{array}{l}\text { Dancing, singing, } \\
\text { painting, carving }\end{array}$ & $\begin{array}{l}\text { Dance, painting, } \\
\text { carving, music } \\
\text { equipments }\end{array}$ \\
\hline 10.Transportation & $\begin{array}{ll}\begin{array}{l}\text { Knowledge } \\
\text { means }\end{array} & \text { of } \\
\text { transportation } & \text { of } \\
\end{array}$ & $\begin{array}{l}\text { The term, } \\
\text { transportation } \\
\text { discourse }\end{array}$ & $\begin{array}{l}\text { Transportation } \\
\text { activities }\end{array}$ & $\begin{array}{l}\text { Bicycles, trains, } \\
\text { cars, planes }\end{array}$ \\
\hline
\end{tabular}

\begin{tabular}{|l|l|l|l|l|l|l}
$\begin{array}{l}\text { Closely } \\
\text { related }\end{array}$ & $\begin{array}{l}\text { Moderately } \\
\text { related }\end{array}$ & Less related
\end{tabular}

Source: developed from Ahimsa-Putra (2013)

From table 1 above, it can be seen that there is a degree of connection between cultural elements and tourism; in this case, the cultural elements as a tourist attraction itself. In the concept of communitybased tourism, the element of culture is one of the important elements in the implementation of tourism activities, namely as an attraction for tourists in determining which cultural attractions or activities to choose for their tour. This is in accordance with the definition put forward by several experts regarding community-based tourism.

Salazar (2012) states that the main strength of community-based tourism, especially in cultural tourism, lies in its potential to empower rural communities and make a substantial contribution to development and poverty eradication. From this opinion, Mayara and Jones clearly state that culture-based tourism is the main sector in community-based tourism. Community-based tourism allows local people to match their natural and cultural environment with tourists. The community will be aware of the commercial value of its natural and cultural heritage, which can generate economic income through tourism. This will encourage people to manage and preserve their natural and cultural environment. With the existence 
of community-based tourism, the community will earn income as well as participate in sustainable tourism businesses.

This is following the opinion of Nurhidayati and Fandeli (2012), who define community-based tourism as tourism that takes into account and places environmental, social, and cultural sustainability, regulated and owned by the community, for the community. Furthermore, Nurhidayati and Fandeli (2012) try to see community-based tourism not from the economic perspective first, but the aspect of community and environmental capacity building, while the economic aspect becomes an 'induced impact' from the social, cultural, and environmental aspects.

Murphy (1988) views the development of tourism activities as a "community-based activity", namely that the resources and uniqueness of the local community in the form of physical and non-physical elements (traditions and culture) attached to these communities are the main driving elements of tourism activities itself. Dangi and Jamal (2016) hold that community-based tourism refers to tourism that involves community participation and aims to generate benefits for local communities in developing countries by enabling tourists to visit these communities and learn about their culture and the local environment. Likewise, as stated by Hadiwijoyo (2012), community-based tourism is tourism that realizes cultural, social, and economic continuity. This form of tourism is managed and owned by the community, to help tourists to increase their awareness and learn about the community and the local way of life. This stage is the highest level of cultural capital involvement in community-based tourism. Tourists are invited to learn how people live in a certain area, starting from living together (live in), and doing what people in that area do, such as farming, making special food and drinks, learning regional languages, art. area, etc. In the Special Region of Yogyakarta, several tourist attractions offer the experience of living together or live in, one of which is the famous Pentingsari Tourism Village in Pentingsari Hamlet, Umbulharjo Village, Cangkringan District, Sleman, DIY.

\subsection{Community-based tourism opportunities}

Weaver (2010) explained that community-based tourism in the early 1980s was a sine qua non of alternative tourism. The concept of tourism is expected to be a tourist alternative to mass tourism. However, it is starting to be abandoned because it causes more reduction and even destruction of the environment, both the natural environment and the cultural and social environment. As alternative tourism, community-based tourism is a concept that emphasizes reciprocal relationships that are mutually beneficial and respectful between local communities and tourists, not solely tourist satisfaction (Salazar, 2012).

Not only does it provide an alternative in traveling, but it also provides solutions for social and cultural problems in the community. Yotsumoto et al. (2016) explain that Japan has implemented a policy to increase the birth rate, but this has failed. Furthermore, in fixing economic and social problems by inviting manufacturing and building infrastructure companies, however, it encountered obstacles, namely that not all areas were suitable for this policy due to the diversity of geographical, economic, cultural characteristics, etc. Even according to Yotsumoto et al. (2016), Japan is categorized as Cities at Risk of Disappearance. The Japanese government's policy in implementing community-based tourism as a sustainability policy is contained in the following: tourism-based community development became a promising development strategy to revitalize local societies. This strategy is attractive to local governments based on the premise that existing tourist attractions are not needed to implement it and, therefore, the strategy can work for every community (Yotsumoto et al., 2016). One form of planning that is participatory in tourism development is implementing community-based tourism. It is a form of tourism that provides opportunities for local communities to control and be involved in tourism management and development. People who are not directly involved in tourism businesses also benefit.

Thus, in Hausler's (2005) view, community-based tourism is an approach to tourism development that emphasizes local communities (whether directly involved in the tourism industry or not) in the form of providing opportunities (access) in tourism management and development which leads to political empowerment, through a more democratic life, including in sharing profits from tourism activities that are more equitable to local communities. 
Community-based tourism plays an essential role in contributing to the development of sustainable tourism. Sebele (2010), asserts that assessing the impact of community-based natural resource management is seen by many as a win-win situation regarding natural resource conservation and improvement of local people's livelihoods. Community-based tourism provides many benefits for various parties, such as increasing human resource development and creating or providing jobs for local communities. The provision of employment for local communities could directly reduce unemployment and poverty in an area. Also, community-based tourism development could gradually start empowering local communities as hosts and guides. They will develop better communication and presentation skills by showing tourists the value and cultural aspects of local people's lives. Community-based tourism is a participatory process which means that every member of the local community will work together in community-based tourism management in their place. This will increase the sense of unity and trust among fellow members of the local community.

\subsection{Community-based tourism challenges}

On the other hand, community-based tourism is considered a naïve and unrealistic concept to implement (Blackstock, 2005; Johnson, 2010) because of several failures in its application. Wang et al. (2013) emphasize the problem in community-based development is the large movement of young people to urban areas (urbanization), which results in decreased agricultural output, decreased service providers, decreased population, and environmental damage. Similar problems are also explained by Yotsumoto et al. (2016) that rural areas have aging problems and a decline in population due to population movement to metropolitan areas. Furthermore, Yotsumoto et al. (2016) showed that economically, the population's needs and purchasing power decreased. This resulted in reduced tax revenue for the government while providing more services for parents increased. Even Japan is categorized as Cities at Risk of Disappearance.

Planning for tourism areas is also needed in community-based tourism development. Marpaung (2016) believes that the emergence of commercial buildings and illegal settlements in tourism areas can cause spatial and environmental problems. So that tourism planning can be applied as a controller for the development of the area. Weaver (2010) looks from a different point of view in seeing the problems that arise from community-based tourism development. According to Weaver, one of the strengths of the concept of community-based tourism is the participation of the community in managing and determining decisions in community-based tourism development in their region. However, this can also be a weakness and can lead to conflict in the future, which is caused by a struggle for management and conflicts of interest between local communities as well as problems in the use of tourism resources in the area.

In the context of the relationship between host and guest, the fulfillment of tourists' needs by the community that occurs often appears as an imposition of the will of tourists on the local community. Tourists ask for what they want instead of coming from the potential local supply of the local community, so that sometimes the authenticity of the local community is not emphasized (Saarinen and Manwa, 2008). Mathieson and Wall (1982) explained that tourism that is not well managed will harm many aspects, the negative impact of which is too much dependence on tourism, increasing inflation rates, and skyrocketing land prices, increasing the tendency to import materials to fulfill tourism needs, uncertainty in making investment capital due to the seasonal nature of tourism, and the incidence of other additional costs to the local economy due to damage by tourism. Ownership and management of tourism by local communities is also important in community-based tourism development, local communities are sometimes still in a doubtful position between managing and owning or just being low-cost and low-cost labor in the tourism business (Blackstock, 2005; Deller, 2010; Mtapuri and Giampiccoli, 2016).

Community-based tourism is a development that arises directly from within the community. However, community-based tourism development activities initiated independently by local communities are still rare and usually require external partnership support (Mtapuri and Giampiccoli, 2016; Nair and Hamzah, 2015). This occurs because of limited expertise and capital. Thus, external entities, including the private sector, NGOs and the government, can become initial facilitators or initiators of CBT 
development, so the government must play a central role in community-based tourism development (Dangi and Jamal, 2016). However, this can lead to the nature of community dependence on external stakeholders and the less than the optimal value of benefits received directly by local communities. In fact, according to Mtapuri and Giampiccoli (2016), dependence on outsider can affect taking over authority by outsiders.

Thus, partnerships, both informal and formal, must have two specific characteristics: first, partnerships must be 'temporary', but in the long term and directed to enhance and empower communities to be independent and have greater bargaining power concerning external entities; and Second, the tourism business itself should not be part of the partnership.

\section{Conclusion}

Community-based tourism is often seen as tourism that simply offers local culture. Sometimes, it is just a slogan offered by tourism entrepreneurs to get as much profit as possible. However, this paper tries to show the basic concept of implementing community-based tourism, including the opportunities and challenges that exist. This needs to be considered for future tourism development, especially those based on local communities.

In practice, community-based tourism has two main assets, namely, social capital and cultural capital. Social capital is about important values that need to be built in a community, namely participation, empowerment, ownership, and social (institutional) capital (Veriasa and Waite, 2017). Meanwhile, cultural capital consists of four aspects or forms of culture: aspects of ideas or knowledge culture, linguistic aspects, behavioral aspects of cultural behavior, and physical or cultural aspects of material/objects created by humans. Developed by Ahimsa-Putra (2013), in addition to these elements, culture also has elements; the ten elements are religion, classification, communication, games, preservation, organization, health, economy, art, and transportation. Therefore, these cultural elements can become a cultural tourism attraction / cultural capital for the concept of community-based tourism. The concept of community-based tourism should be tourism that is owned, managed, and initiated by local communities, by utilizing all local potentials, especially cultural capital (traditions and ways of life that are unique and authentic) and social capital, maintaining environmental, social, and cultural sustainability, and providing benefits for community welfare.

Community-based tourism has several opportunities such as the following:

i. Presenting a tourist alternative for mass tourism.

ii. Giving the solution to the socio-cultural problems that occur with a local revitalization strategy to improve the quality of local communities.

iii. Providing opportunities (access) in tourism management and development leads to community empowerment, including the sharing of benefits from tourism activities that are more equitable for local communities.

iv. As tourism with the concept of sustainability, community-based tourism can minimize the impact of environmental damage, both the natural environment and the social and cultural environment.

v. Providing many benefits for various parties, such as increasing human resource development, and opening or providing jobs for local communities.

Community-based tourism development, although it has many benefits and advantages, also has various challenges. Mathieson and Wall (1982) explained that tourism that is not well managed would harm many aspects. Therefore, community-based tourism must be pro-actively managed to minimize any negative impacts caused. This negative impact is a challenge for various parties. Tourism that is not managed properly will cause various kinds of problems that will become challenges. 
These challenges are as follows:

i. The existence of conflict between tourists and local communities due to differences in perceptions and urbanization activities of young people, is very disturbing to the development of rural areas because young people become one of the assets of local human resources that support tourism.

ii. Problems arise due to conflicts of interest between local communities as well as problems in the use of tourism resources in the area.

iii. Fulfilling the needs of tourists by the community that occurs often appears as an imposition of the will of tourists on local communities. Tourists ask for what they want, not from the local potential supply of the local community

iv. High dependence of the community on seasonal tourism activities.

v. Unclear ownership status of community-based tourism development where the local community is still in a position between managing and owning or only being a workforce.

vi. In community-based tourism development, local communities usually still need support from partnerships; this can lead to the nature of community dependence on partnerships, resulting in less than the optimal value of benefits received directly by local communities.

The need to increase the capacity and quality of local communities is needed to increase the satisfaction of visiting tourists as well as to absorb the positive impact of carrying out these tourism activities. This is so that the development of the area needs to be understood in stages, to be able to implement community-based tourism as one of the right and applicable concepts. To maximize the positive impact or benefits of community-based tourism, it is necessary to increase coordination and interaction between local communities and other parties. The concept of community-based tourism itself seeks to answer how tourism can contribute to the development process of local communities and become a model for tourism development that can prevent changes in community values and culture and make it an attraction for tourists. This should be done so that community-based tourism is very strategic as a concept in tourism development.

\section{Limitations and study forward}

This research has limitations, which may contribute to other research in the future. This research is based on secondary data. Similar research in the future can focus on primary data and case studies directly at certain locations, which are related to community-based tourism. Future studies can also explore the benefits and institutional aspects, as well as the success and future prospects of this concept.

\section{Acknowledgment}

We would like to express our gratitude to the Indonesian Endowment Fund for Education (LPDP) Scholarship under the Indonesia-Domestic Lecturer Excellence Scholarship (BUDI-DN) 2017.

\section{References}

Adimihardja, K. (1999). Petani: Merajut tradisi era globalisasi. Mendayagunakan sistem pengetahuan lokal dalam pembangunan yang berwawasan lingkungan dan berkelanjutan. Humaniora.

Ahimsa-Putra, H. S. (2013). Budaya bangsa, jati diri dan integrasi nasional: Sebuah teori. Jejak Nusantara, 1, 6-19.

APEC. (2014). APEC tourism ministerial meeting: Seoul declaration on an APEC Tourism Charter. www.apec.org/MeetingPapers/Ministerial-Statements/Tourism/2000_tourism.aspx

Blackstock, K. (2005). A critical look at community based tourism. Community Development Journal, 40(1), 39-49. https://doi.org/10.1093/cdj/bsi005

Campbell, L. M., \& Vainio-Mattila, A. (2003). Participatory Development and community-based conservation: Opportunities missed for lessons learned? Human Ecology, 3(3), 239-248. https://doi.org/10.1023/A

Carr, A., Ruhanen, L., \& Whitford, M. (2016). Indigenous peoples and tourism: the challenges and opportunities for sustainable tourism. Journal of Sustainable Tourism, 24(8-9), 1067-1079. 
https://doi.org/10.1080/09669582.2016.1206112

Crow, G., \& Allen, G. (1994). Community Life: An Introduction to Local Social Relations. HarvesterWheatsheaf.

Dangi, T. B., \& Jamal, T. (2016). An integrated approach to "sustainable community-based tourism." Sustainability (Switzerland), 8(5). https://doi.org/10.3390/su8050475

Deller, S. (2010). Rural poverty, tourism and spatial heterogeneity. Annals of Tourism Research, 37(1), 180-205. https://doi.org/10.1016/j.annals.2009.09.001

Denman, R. (2001). Guidelines for community-based ecotourism development (W. International (ed.)).

Dimitrovski, D. D., Todorovic, A. T., \& Valjarevic, A. (2012). Rural tourism and regional development : Case study of development. 14, 288-297. https://doi.org/10.1016/j.proenv.2012.03.028

Dolezal, C. (2011). Community-based tourism in Thailand: (Dis-)Illusions of authenticity and the necessity for dynamic concepts of culture and power. ASEAS - Austrian Journal of South-East Asian Studies, 4(1), 129-138.

Gezici, F., Yazgan Gül, A., \& Alkay, E. (2006). Analyzing coastal development pattern of tourism in Turkey. 46th Congress of European Regional Science Association 30 August- 3 September 2006 Volos, Greece, May 2014, 1-26. http://www.ersa.org/ersaconfs/ersa06/papers/494.pdf

Ghaderi, Z., \& Henderson, J. C. (2012). Sustainable rural tourism in Iran: A perspective from Hawraman Village. Tourism Management Perspectives, 2-3, 47-54. https://doi.org/10.1016/j.tmp.2012.03.001

Goodwin, H., \& Santili, R. M. (2009). Community-based tourism: A Success? International Centre for Responsible Tourism, Leeds Metropolitan University. http://www.icrtourism.org/documents/OP11merged.pdf

Hadiwijoyo, S. S. (2012). Perencanaan pariwisata perdesaan berbasis masyarakat: Sebuah pendekatan konsep. Graha Ilmu.

Hasanah, M. (2017). Pengelolaan pariwisata alam berbasis masyarakat. Universitas Hasanudin.

Hausler, N. (2005). Definition of community based tourism. Tourism Forum International at the Reisepavillon.

Inskeep, E. (1991). Tourism Planning: an Integrated and Sustainable Development Approach. Van Nostrand Reinhold.

Johnson, P. A. (2010). Realizing rural community based tourism development: Prospects for socialeconomy enterprises. Journal of Rural and Community Development, 5(1), 150-162.

Koentjaraningrat. (2015). Pengantar Ilmu Antropologi. Rineka Cipta.

Kottak, C. P. (2011). Cultural anthropology: Appreciating cultural diversity. The McGraw-Hill Companies.

Liu, C.-Z. (2010). Rural development and rural tourism in Taiwan. Asian Journal of Arts and Sciences, 1(2), 211-227. internal-pdf://183.243.124.59/Taiwan rural areas, rural tourism.pdf

Malinowski, B. (1922). Argonauts of the western pacific: An account of native enterprise and adventure in the archipelagoes of Melanesian New Guinea (First Edit). G. Routledge \& Sons.

Marpaung, B. O. (2016). Communication strategy planning of fisherman kampung Medan Belawan as a tourist destination. Procedia - Social and Behavioral Sciences, 234, 344-352. https://doi.org/10.1016/j.sbspro.2016.10.251

Mathieson, A., \& Wall, G. (1982). Tourism economy physical and social impact. Longman Group.

Mtapuri, O., \& Giampiccoli, A. (2016). Towards a comprehensive model of community-based tourism development. South African Geographical Journal, 98(1), 154-168. https://doi.org/10.1080/03736245.2014.977813

Mualisin, I. (2007). Model pengembangan pariwisata berbasis masyarakat di kota Yogyakarta. Jurnal Penelitian Bappeda Kota Yogyakarta, 2(2), 34-36.

Murphy, P. E. (1988). Community driven tourism planning. Tourism Management, 9(2), 96-104.

Musavengane, R. (2015). Does social capital really enhance community based ecotourism? A review of the literature. African Journal of Hospitality, Tourism and Leisure, 4(41).

Nair, V., \& Hamzah, A. (2015). Successful community-based tourism approaches for rural destinations. Worldwide Hospitality and Tourism Themes, 7(5), 429-439.

https://doi.org/10.1108/WHATT-06-2015-0023 
Nechifor, C. I. (2014). Tourism and sustainable development. Implications at local community level. Economica, 10(5), 1-36.

Nurhidayati, S. E., \& Fandeli, C. (2012). Penerapan prinsip Community Based Tourism ( CBT ) dalam pengembangan agrowisata di Kota Batu, Jawa Timur. Jejaring Administrasi Publik, IV(1), 36-46.

Radcliffe-Brown, A. . (1952). Structure and Function in Primitive Society. Cohen and West Ltd.

Saarinen, J., \& Manwa, H. (2008). Tourism as a Socio-cultural encounter: Host-guest relations in tourism development in Botswana. Botswana Notes and Records, 39(January), 43-53. https://doi.org/10.2307/41236632

Salazar, N. B. (2012). Community-based cultural tourism: Issues, threats and opportunities. Journal of Sustainable Tourism, 20(1), 9-22. https://doi.org/10.1080/09669582.2011.596279

Sebele, L. S. (2010). Community-based tourism ventures, benefits and challenges: Khama Rhino Sanctuary Trust, Central District, Botswana. Tourism Management, 31(1), 136-146. https://doi.org/10.1016/j.tourman.2009.01.005

Siwi, M. (2012). Konsep Komunitas dan masyarakat dalam perspektif sosiologi. Departemen SKPM IPB. http://skpm.ipb.ac.id/web/konsep-komunitas-dan-masyarakat-dalam-perspektif-sosiologi/

Sunaryo, B. (2013). Kebijakan pembangunan destinasi pariwisata konsep dan aplikasinya di Indonesia. Gava Media.

Tolkach, D., \& King, B. (2015). Strengthening community-based tourism in a new resource-based island nation: Why and how? Tourism Management, 48, 386-398. https://doi.org/10.1016/j.tourman.2014.12.013

Veriasa, T. O., \& Waite, M. (2017). Memahami Konsep "Pengembangan Komunitas". Pusat Pengkajian Perencanaan dan Pengembangan Wilayah (P4W). Institut Pertanian Bogor. https://www.researchgate.net/publication/321753533

Walkowski, M. da C., Pires, P. dos S., \& Tricárico, L. T. (2019). Community-based tourism initiatives and their contribution to sustainable local development. Journal of Sustainable Tourism and Entrepreneurship, 1(1), 55-67. https://doi.org/10.35912/joste.v1i1.203

Wang, L. en, Cheng, S. kui, Zhong, L. sheng, Mu, S. lin, Dhruba, B. G. C., \& Ren, G. zhu. (2013). Rural tourism development in China: Principles, models and the future. Journal of Mountain Science, 10(1), 116-129. https://doi.org/10.1007/s11629-013-2501-3

Weaver, D. (2010). Community-based tourism as strategic dead-end. Tourism Recreation Research, 35(2), 206-208. https://doi.org/10.1080/02508281.2010.11081635

Widayanti, S. (2012). Pemberdayaan masyarakat: Pendekatan teoritis. Ilmu Kesejahteraan Sosial, $1(1), 87-102$.

Xi, J., Wang, X., Kong, Q., \& Zhang, N. (2015). Spatial morphology evolution of rural settlements induced by tourism: A comparative study of three villages in Yesanpo tourism area, China. Journal of Geographical Sciences, 25(4), 497-511. https://doi.org/10.1007/s11442-015-1182-y

Ying, T., \& Zhou, Y. (2007). Community, governments and external capitals in China's rural cultural tourism: A comparative study of two adjacent villages. Tourism Management, 28(1), 96-107. https://doi.org/10.1016/j.tourman.2005.12.025

Yotsumoto, Y., Han, J., \& Hatada, N. (2016). An overview of Japanese tourism - based community development: Definitions and successes. Politic and Economic, 25(2), 177-195. 